\title{
Diffusion Bonding and Post-Weld Heat Treatment of Extruded AZ91 Magnesium Alloys
}

\author{
Fei LIN $^{1 *}$, YaXin TIAN ${ }^{1}$, ZhiTong CHEN ${ }^{1}$, Fei WANG $^{2}$, QingSen MENG ${ }^{1}$ \\ ${ }^{1}$ College of Materials Science and Engineering, Taiyuan University of Technology.79 West Yingze Street, Taiyuan, \\ Shanxi, 030024, China \\ ${ }^{2}$ College of Mining Engineering, Taiyuan University of Technology.79 West Yingze Street, Taiyuan, Shanxi, 030024, \\ China \\ cross $^{\text {ref }}$ http://dx.doi.org/10.5755/j01.ms.21.4.9699
}

Received 26 October 2015; accepted 16 November 2015

\begin{abstract}
The grain size of as-extruded AZ91 magnesium alloys was refined to $12.31 \mu \mathrm{m}$ from $21.41 \mu \mathrm{m}$ by recrystallization annealing. The vacuum diffusion welding of as-annealed AZ91 magnesium alloys was researched. The results showed that the maximum shear strength of joints reached $64.70 \mathrm{MPa}$ in the situation of $10 \mathrm{MPa}$ bonding pressure, $18 \mathrm{~Pa}$ vacuum degree, $470{ }^{\circ} \mathrm{C}$ bonding temperature and $90 \mathrm{~min}$ bonding time; both bonding temperature and time are the main influence factors on as-extruded AZ91 magnesium alloys diffusion welding. Then the diffusion welded specimens were annealed, and the shear strength of joints was further improved to $76.93 \mathrm{MPa}$.

Keywords: AZ91 magnesium alloys, recrystallization anneal, diffusion bonding, shear strength, post-weld heat treatment.
\end{abstract}

\section{INTRODUCTION}

Magnesium alloys have attracted great attention in many areas recently due to the good features such as good damping characteristics and low density $[1-5]$. However, magnesium alloys also have high coefficient of linear expansion and low melting point. It is easy to form cracks in the conventional welding techniques such as tungsten inert gas arc welding, laser beam welding and friction welding [6, 7]. Diffusion bonding is an effective method to reduce air holes, cracks and welding deformation $[8,9]$. Recently, a lot of researches have been carried out on this kind of welding method [10,11]. Researches about diffusion bonding can be used in the welding of complex and precision parts. However, the residual stress still exists in diffusion bonding. Post-weld heat treatment is an effective way to eliminate the residual stress of magnesium alloys in the welding process and improve the performance of the joints [12-14]. The purpose of this paper is to explore the feasibility of magnesium alloy vacuum diffusion bonding and the effectiveness of post-weld heat treatment for improving the joint strength.

\section{EXPERIMENTAL DETAILS}

The starting material was as-extruded AZ91 magnesium alloys of composition: $\mathrm{Mg}-9 \mathrm{wt} . \% \mathrm{Al}-$ 1 wt. $\% \mathrm{Zn}$. The material, that had been cut into cube with $10 \mathrm{~mm} \times 10 \mathrm{~mm} \times 10 \mathrm{~mm}$ by wire cutting machine, was refined to make the diffusion more efficient [15]. Recrystallization anneal made the average grain size of AZ91 refined to $12.31 \mu \mathrm{m}$ from $21.41 \mu \mathrm{m}$ at $300{ }^{\circ} \mathrm{C}$ for the duration of $30 \mathrm{~min}$. The specimens were bonded at $430{ }^{\circ} \mathrm{C}$,

\footnotetext{
* Corresponding author. Tel.: +86-13233686808.

E-mail address: lzlfxfc@126.com (F. Lin)
}

$450{ }^{\circ} \mathrm{C}, 470{ }^{\circ} \mathrm{C}$ and $490{ }^{\circ} \mathrm{C}$ for durations of $60 \mathrm{~min}, 90 \mathrm{~min}$ and 120 min under $10 \mathrm{MPa}$ pressure in a vacuum of $18 \mathrm{~Pa}$ using VFB-150/200 vacuum furnace. The heating rate of the furnace was kept $20-30{ }^{\circ} \mathrm{C} / \mathrm{min}$. Post-weld heat treatment was carried out on the joints at $320^{\circ} \mathrm{C}, 350{ }^{\circ} \mathrm{C}$ and $380{ }^{\circ} \mathrm{C}$ for durations of $1-5 \mathrm{~h}$ according to references [16]. After the post-weld heat treatment, microstructure was studied by optical microscopy. The shear test was performed in universal testing machine with loading speed of $1 \mathrm{~mm} / \mathrm{min}$.

\section{RESULTS AND DISCUSSION}

\subsection{The grain refining}

The starting material had coarse grains. After the heat treatment, the grain size was refined to $12.31 \mu \mathrm{m}$ from $21.41 \mu \mathrm{m}$. Their microstructures are shown in Fig. 1.

\subsection{The effect of temperature}

The micrographs of joints at different diffusion temperature for $90 \mathrm{~min}$ are shown in Fig. 2. As can be seen from Fig. 2, when temperature was $450{ }^{\circ} \mathrm{C}$, the bonding line was obvious. Because at the lower temperature, atoms could not obtain enough energy, and the diffusion of atoms was not sufficient. As the temperature increased to $470{ }^{\circ} \mathrm{C}$, atoms obtained more abundant energy, and the capability of atomic diffusion was gradually enhanced. The conjunct grains appeared in the weld area, and the bonding line was obviously thinner. As the temperature increased to $490{ }^{\circ} \mathrm{C}$, grain growth was very obvious. Hence, appropriate temperature can make atoms spread quickly within the limited holding time. High bonding temperature leaded to rapid grain growth, and low bonding temperature leaded to insufficient atomic diffusion. 


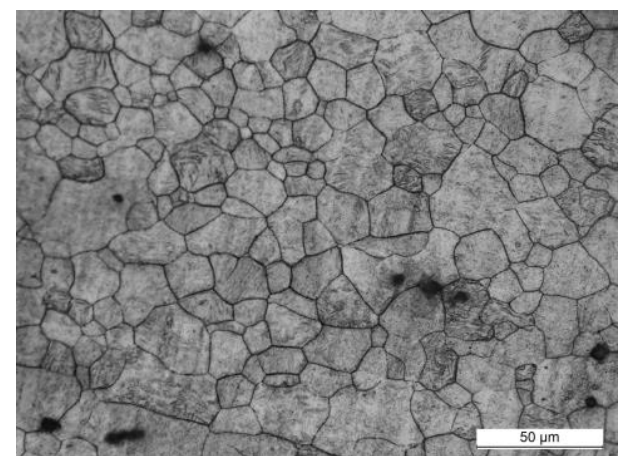

a

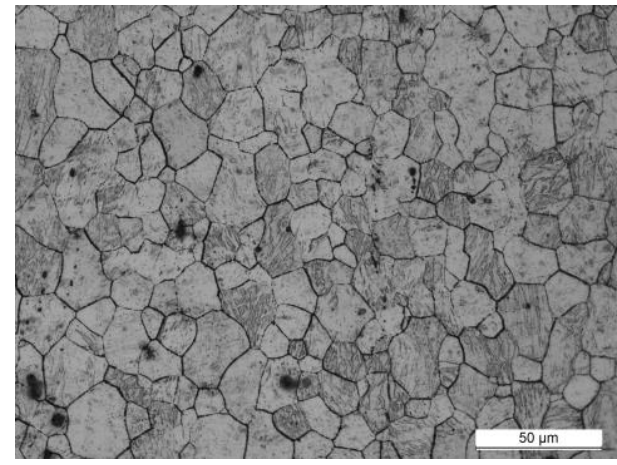

$\mathrm{b}$

Fig. 1. Microstructures of AZ91: $a$-original; $b$-annealing at $300{ }^{\circ} \mathrm{C}$ for $30 \mathrm{~min}$

\subsection{The effect of holding time}

The joint micrographs in different bonding time at $470{ }^{\circ} \mathrm{C}$ are shown in Fig. 3. When the bonding time was $60 \mathrm{~min}$, the bonding line was clearly visible. When the bonding time increased to $90 \mathrm{~min}$, only a few conjunct grains existed in the weld area, and the bonding line was obviously thinner. Due to insufficient time, atoms didn't spread sufficiently. Grain recrystallization and growth process did not complete in the weld area. Because the atomic diffusion was fuller, more conjunct grains existed in the weld area, and weld line was significantly thinner.
When the holding time increased to $120 \mathrm{~min}$, atomic diffusion was fuller, the weld continued to fade. However, grains of joint continued to grow up.

According to the basic theory of diffusion bonding, increasing the bonding time can effectively improve the effect of diffusion bonding, but when the bonding time exceeded a certain value, the quality of diffusion welding joint were unable to get improved. So it is crucial to choose a suitable bonding time.

\subsection{The shear strength}

In order to determine the optimum parameters of diffusion bonding, joint shear strength was tested. Two welded specimens were tested in each parameter, and took the average. The standard deviation is $\pm 0.5 \%$. The results are shown in Table 1.

Welding joints did not combine effectively at $430{ }^{\circ} \mathrm{C}$ for $60 \mathrm{~min}$. As temperature increased, joint strength for 60 min became large. The extension of bonding time was beneficial to diffusion and the improvement of the mechanical property of welded joints at low temperatures. When bonding time was $90 \mathrm{~min}$ and $120 \mathrm{~min}$, with the increase of temperature, the shear strength increased firstly and then decreased.

Test results show that $470{ }^{\circ} \mathrm{C}$ is the ideal bonding temperature. In this case, diffusion coefficient, atomic activity and diffusion efficiency greatly increased compared with $450{ }^{\circ} \mathrm{C}$. When the holding time was less than $90 \mathrm{~min}$, the joint strength continued to increase. However, when the holding time was $120 \mathrm{~min}$, the joint strength decreased slightly. Diffusion was still enhanced, but grain size had already become large. The negative impact of increased grain size was larger than the positive impact of diffusion, so joint quality declined slightly. Therefore, the maximum of joint shear strength was 64.70 $\mathrm{MPa}$ at $470^{\circ} \mathrm{C}$ for $90 \mathrm{~min}$, and the joint shear strength is affected by the bonding temperature and time.
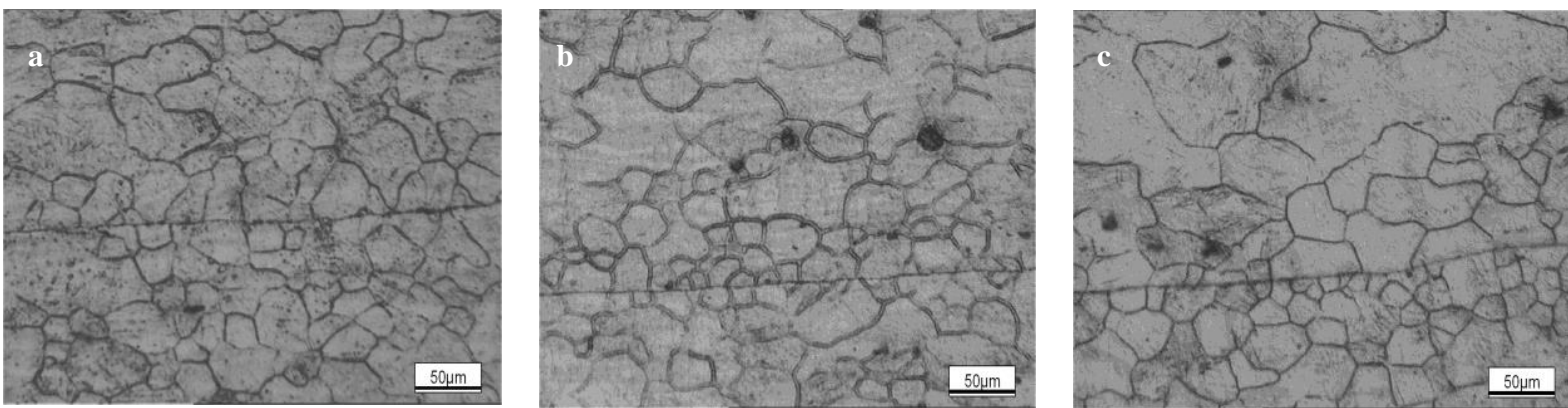

Fig. 2. Microstructures of diffusion bonding joints: $\mathrm{a}-450{ }^{\circ} \mathrm{C} \times 90 \mathrm{~min} ; \mathrm{b}-470{ }^{\circ} \mathrm{C} \times 90 \mathrm{~min} ; \mathrm{c}-490{ }^{\circ} \mathrm{C} \times 90 \mathrm{~min}$
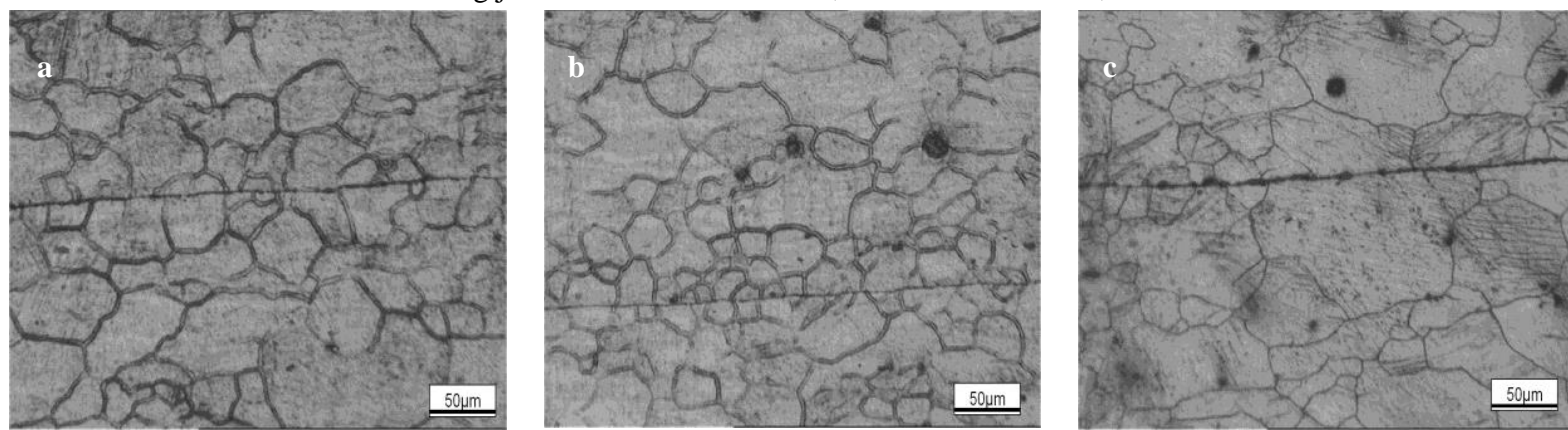

Fig. 3. Microstructures of diffusion bonding joints: $\mathrm{a}-470{ }^{\circ} \mathrm{C} \times 60 \mathrm{~min} ; \mathrm{b}-470{ }^{\circ} \mathrm{C} \times 90 \mathrm{~min} ; \mathrm{c}-470{ }^{\circ} \mathrm{C} \times 120 \mathrm{~min}$ 
Table 1. Joint shear strength in different parameters

\begin{tabular}{|c|c|c|c|}
\hline $\begin{array}{c}\text { Processing } \\
\text { parameter, } \\
{ }^{\circ} \mathrm{C} \times \min \end{array}$ & $\begin{array}{c}\text { Maximum shear } \\
\text { strength, MPa }\end{array}$ & $\begin{array}{c}\text { Minimum shear } \\
\text { strength, MPa }\end{array}$ & $\begin{array}{c}\text { The average } \\
\text { shear } \\
\text { strength, MPa }\end{array}$ \\
\hline $430 \times 60$ & - & - & - \\
\hline $430 \times 90$ & - & - & - \\
\hline $430 \times 120$ & 12.57 & 8.40 & 10.73 \\
\hline $450 \times 60$ & 22.78 & 19.35 & 21.56 \\
\hline $450 \times 90$ & 29.82 & 25.68 & 28.21 \\
\hline $450 \times 120$ & 41.66 & 35.92 & 39.79 \\
\hline $470 \times 60$ & 53.98 & 48.84 & 52.41 \\
\hline $470 \times 90$ & 66.90 & 60.85 & 64.70 \\
\hline $470 \times 120$ & 59.74 & 51.90 & 56.37 \\
\hline $490 \times 60$ & 57.08 & 52.33 & 54.72 \\
\hline $490 \times 90$ & 62.15 & 57.95 & 60.48 \\
\hline $490 \times 120$ & 47.92 & 39.93 & 44.78 \\
\hline
\end{tabular}

\subsection{Post-weld heat treatment}

After welding at $470{ }^{\circ} \mathrm{C}$ for $90 \mathrm{~min}$, the specimens were annealed, and then joint shear strength was tested. Two specimens were tested in each parameter and took the average was found. The results are shown in Table 2.

Table 2. Shear strength of as-annealed joints in different parameters

\begin{tabular}{|c|c|c|c|}
\hline $\begin{array}{c}\text { Processing } \\
\text { parameter, } \\
{ }^{\circ} \mathrm{C} \times \mathrm{h}\end{array}$ & $\begin{array}{c}\text { Maximum } \\
\text { shear } \\
\text { strength, } \\
\mathrm{MPa}\end{array}$ & $\begin{array}{c}\text { Minimum } \\
\text { shear } \\
\text { strength, } \\
\mathrm{MPa}\end{array}$ & $\begin{array}{c}\text { The average } \\
\text { shear strength, } \\
\mathrm{MPa}\end{array}$ \\
\hline $320 \times 1$ & 65.67 & 62.57 & 64.12 \\
\hline $320 \times 2$ & 68.75 & 67.31 & 68.03 \\
\hline $320 \times 3$ & 72.86 & 70.50 & 71.69 \\
\hline $320 \times 4$ & 74.38 & 72.74 & 73.57 \\
\hline $320 \times 5$ & 76.85 & 74.03 & 75.45 \\
\hline $350 \times 1$ & 69.78 & 67.86 & 68.82 \\
\hline $350 \times 2$ & 72.36 & 70.62 & 71.49 \\
\hline $350 \times 3$ & 75.94 & 74.10 & 75.02 \\
\hline $350 \times 4$ & 78.02 & 75.86 & 76.93 \\
\hline $350 \times 5$ & 78.34 & 75.96 & 77.15 \\
\hline $380 \times 1$ & 70.86 & 66.98 & 68.92 \\
\hline $380 \times 2$ & 72.11 & 68.94 & 70.53 \\
\hline $380 \times 3$ & 71.36 & 67.98 & 69.67 \\
\hline $380 \times 4$ & 69.80 & 66.74 & 68.28 \\
\hline $380 \times 5$ & 66.21 & 65.65 & 65.93 \\
\hline
\end{tabular}

As can be seen from Table 2, magnesium alloy joint strength was improved after post-weld heat treatment.

Specimens that had been treated at $350{ }^{\circ} \mathrm{C}$ for $4 \mathrm{~h}$ were analysed. In Fig. 4, microstructures of the joints that had been welded at $470{ }^{\circ} \mathrm{C}$ for $90 \mathrm{~min}$ without and after heat treatment are shown in $\mathrm{a}$ and $\mathrm{b}$ respectively. After a long time of atomic diffusion, welding line narrowed obviously.

The conjunct grains were uniform and fine. The grain size away from the weld area of specimens after the heat treatment became slightly large, but that of the weld area did not change significantly. However, compared with welded specimens without heat treatment, the grain size of weld area was relatively uniform, because microscopic plastic deformation had occurred in the weld area.
Diffusion still existed in the annealing heat treatment process. In order to improve the strength of the welded joint, it is necessary to improve the interface mobility. A better interface mobility can get at higher temperatures. When the annealing temperature was $350{ }^{\circ} \mathrm{C}$, in the case of enough time, the weld line had almost disappeared. If the temperature continued to rise, only considering the role of diffusion, the strength would still be improved. However, parent metal grain size also continued to grow, and the performance of the parent metal was affected.

Time is a factor affecting the diffusion. When temperature was $320{ }^{\circ} \mathrm{C}$ and $350{ }^{\circ} \mathrm{C}$, with the increase of annealing holding time, the joint strength was gradually improved. When the time reached $4 \mathrm{~h}$, joint strength was no longer significantly improved at $350{ }^{\circ} \mathrm{C}$. Due to the higher annealing temperature, holding time was much longer than the annealing time of wrought magnesium alloys, and grain growth was obvious. The performance of the parent metal would decrease to some extent. However, the weld area grain size in the process of post-weld heat treatment was still fine and more uniform, due to the plastic deformation and fine grain in the process of diffusion welding. If the holding time further increased, the grain of the weld area would further grow.

Some other researchers have also studied the vacuum diffusion bonding of AZ91 magnesium alloys, and the optimal shear strength of joints is $52.83 \mathrm{MPa}$ at the same parameters of $470{ }^{\circ} \mathrm{C}$ for $90 \mathrm{~min}$ [17]. The results show that the joint shear strength of specimens after post-weld heat treatment is obviously improved and much greater than 52.83 $\mathrm{MPa}$. It proves that post-weld heat treatment is an effective way to improve the effect of diffusion bonding.

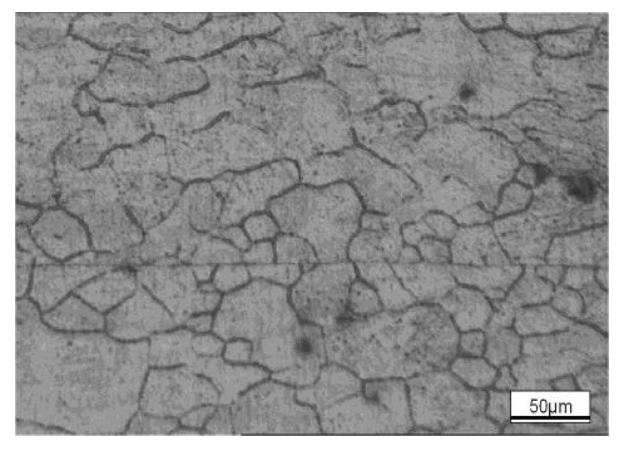

a

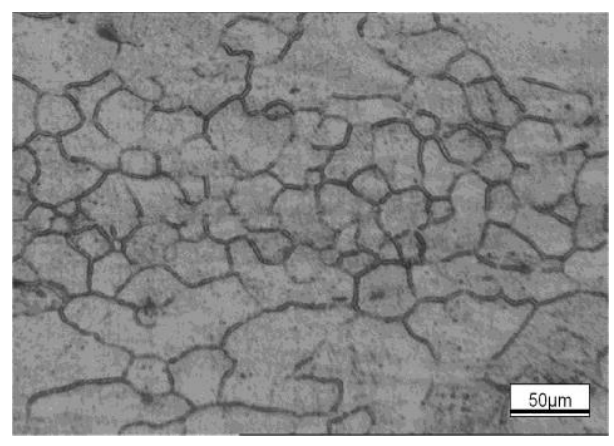

Fig. 4. Microstructures of diffusion bonding joints: a-without post-weld heat treatment; $\mathrm{b}$-after annealing at $350{ }^{\circ} \mathrm{C}$ for $4 \mathrm{~h}$ 


\section{CONCLUSIONS}

1. The grain size of AZ91 magnesium alloys was refined to $12.31 \mu \mathrm{m}$ from $21.41 \mu \mathrm{m}$ at $300{ }^{\circ} \mathrm{C}$ for $30 \mathrm{~min}$.

2. Diffusion bonding at $4300^{\circ} \mathrm{C}, 450{ }^{\circ} \mathrm{C}, 470{ }^{\circ} \mathrm{C}$ and $490^{\circ} \mathrm{C}$ for durations of $60 \mathrm{~min}, 90 \mathrm{~min}$ and $120 \mathrm{~min}$ under $10 \mathrm{MPa}$ pressure in a vacuum of $18 \mathrm{~Pa}$ was all realized; $470{ }^{\circ} \mathrm{C}$ and $90 \mathrm{~min}$ were the optimal technological parameters of vacuum diffusion bonding. The maximum shear strength reached 64.70 MPa. The quality of the welded joints was affected by the bonding temperature and time. At the higher bonding temperature, the holding time should be shortened accordingly to avoid grain growth. At the lower bonding temperature, the holding time must be appropriately extended to make diffusion full and improve the performance of joints.

3. Post-weld heat treatment was carried out on welded specimens whose mechanical property was best. The shear strength was improved to $76.93 \mathrm{MPa}$ from 64.70 MPa.

\section{Acknowledgement}

This investigation was performed under the National Natural Science Foundation (51374152).

\section{REFERENCES}

1. Aghion, E., Bronfin, B. Magnesium Alloys Development Towards the 21st Century Magnesium Science Forum 350 2000: pp. 19-28.

http://dx.doi.org/10.4028/www.scientific.net/MSF.350351.19

2. Wang, Q.D., Ding, W.J. Status and Prospects of Magnesium Alloys Research and Development World Nonferrous Metals 7 2004: pp. 8-11.

3. Li, N., Zheng, Y.F. Novel Magnesium Alloys Developed for Biomedical Application: a Review Journal of Materials Science \& Technology 2013: pp. 489-502.

http://dx.doi.org/10.1016/j.jmst.2013.02.005

4. Hirsch, J., Al-Samman, T. Superior Light Metals by Texture Engineering: Optimized Aluminum and Magnesium Alloys for Automotive Applications Acta Materialia 61 2013: pp. 818-843. http://dx.doi.org/10.1016/j.actamat.2012.10.044

5. Frank, C. Controlling the Ignition and Flammability of Magnesium for Aerospace Applications Corrosion Science 86 2014: pp. 1-16. http://dx.doi.org/10.1016/j.corsci.2014.04.047

6. Liang, G.L., Yuan, S.Q. Study on TIG Welding Technology of AZ31B Magnesium Alloys Hot Working Technology 37 2008: pp. 56-57.
7. Sun, D.Q., Lang, B., Sun, D.X. Microstructures and Mechanical Properties of Resistance Spot Welded Magnesium Alloys Joint China Welding 15 2006: pp. 494-498.

8. Mahendran, G., Balasubramanian, V., Senthilvelan, T. Developing Diffusion Bonding Windows for Joining AZ31B Magnesium-AA2024 Aluminium Alloys Materials \& Design 30 2009: pp. $1240-1244$. http://dx.doi.org/10.1016/j.matdes.2008.06.015

9. Zhang, J., Luo, G.Q., Wang, Y.Y., $\quad$ Shen, Q., Zhang, L.M. An Investigation on Diffusion Bonding of Aluminum And Magnesium Using a Ni Interlayer Materials Letters 83 2012:pp. 189-191. http://dx.doi.org/10.1016/j.matlet.2012.06.014

10. Wang, Y.Y., Luo, G.Q., Zhang, J., Shen, Q., Zhang, L.M. Microstructure and Mechanical Properties of Diffusion-Bonded Mg-Al Joint Using Silver Film as Interlayer Materials Science and Engineering A 559 2013: pp. 868-874. http://dx.doi.org/10.1016/j.msea.2012.09.035

11. Shang, J., Wang, K.H., Zhou, Q., Zhang, D.K., Huang, J., Ge, J.Q. Effect of Jioning Temperature on Microstructure and Properties of Diffusion Bonded $\mathrm{Mg} / \mathrm{Al}$ Joints Transactions of Nonferrous Metals Society of China 22 2012: pp. 1961-1966. http://dx.doi.org/10.1016/S1003-6326(11)61414-3

12. Zhou, H.F., Zhang, X.D., Zhang, Q. Influence of Heat Treatment Condition on Bonding Productivity During Vacuum Diffusion Bonding Journal of Jiang Han Petroleum Institute 18 1996: pp. 82-84.

13. Xie, Y.D., Nong, Q. Effects of Post-Weld Heat Treatment on Microstructures and Mechanical Properties of Aluminum Allot 6061 Welded Joints Hot Working Technology 40 2011: pp. 127-129.

14. Arenas, M.F., Acoff, V.L. The Effect of Postweld Heat Treatment on Gas Tungsten Arc Welded Gamma Titanium Aluminide Scripta Materialia 46 2002: pp. $241-246$. http://dx.doi.org/10.1016/S1359-6462(01)01232-5

15. Hidetoshi, S., Hiroyuki, H., Hiroyuki, W. Diffusion Bonding in Superplastic Magnesium Alloys Material Science and Engineering A 339 2003: pp. 328-333. http://dx.doi.org/10.1016/S0921-5093(02)00127-2

16. Li, Y. J. Advanced Materials Welding Technology, Chemical Industry Press, Beijing, 2012.

17. Lin, F., Sun, L. L. Study on Vacuum Diffusion Bonding of Extruded AZ91 Magnesium Alloys Welding Technology 41 2012: pp. 19-21. 